\title{
Karin Ueltschi, La «Mesnie Hellequin» en conte et en rime. Mémoire mythique et poétique de la recomposition
}

\section{G. Matteo Roccati}

\section{CpenEdition}

1 Journals

\section{Édition électronique}

URL : https://journals.openedition.org/studifrancesi/4594

DOI : 10.4000/studifrancesi.4594

ISSN : 2427-5856

Éditeur

Rosenberg \& Sellier

\section{Édition imprimée}

Date de publication : 1 avril 2012

Pagination : 119-120

ISSN : 0039-2944

\section{Référence électronique}

G. Matteo Roccati, « Karin Ueltschi, La «Mesnie Hellequin» en conte et en rime. Mémoire mythique et poétique de la recomposition », Studi Francesi [En ligne], 166 (I | LVI) | 2012, mis en ligne le 30 novembre 2015, consulté le 19 novembre 2021. URL : http://journals.openedition.org/studifrancesi/4594 ; DOI : https://doi.org/10.4000/studifrancesi.4594

Ce document a été généré automatiquement le 19 novembre 2021.

\section{(c) $(1) \odot$}

Studi Francesi è distribuita con Licenza Creative Commons Attribuzione - Non commerciale - Non opere derivate 4.0 Internazionale. 
Karin Ueltschi, La «Mesnie Hellequin» en conte et en rime. Mémoire mythique et poétique de la recomposition

G. Matteo Roccati 


\section{RÉFÉRENCE}

KARIN UELTSCHI, La «Mesnie Hellequin» en conte et en rime. Mémoire mythique et poétique de la recomposition, Paris, Honoré Champion Éditeur, 2008 («Nouvelle bibliothèque du Moyen Âge», 88), pp. 780.

1 Etude, foisonnante et suggestive, des matériaux très divers qui se rattachent à la croyance mythique de la mesnie Hellequin. Un premier chapitre passe en revue et commente les témoins tant latins (reproduits en annexe, depuis Orderic Vital, XII ${ }^{\mathrm{e}}$-XIV ${ }^{\mathrm{e}}$ s.) que français ( $\mathrm{XII}^{\mathrm{e}}-\mathrm{XVI}^{\mathrm{e}} \mathrm{s}$.), le corpus étant limité aux textes où le nom de Hellequin apparaît explicitement. «Les résultats de cette analyse - selon les mots de l'A. - nous fourniront les constantes circonstancielles solidement établies autour du nom. A partir de là nous pourrons définir les mythèmes (...) appartenant au conglomérat hellequinien, mythèmes que nous pourrons alors rechercher dans des textes ayant effacé non seulement le nom de notre figure mais jusqu'à tout indice permettant de l'identifier spontanément» (p. 25). Les chapitres suivants-qui se cantonnent volontairement à la sphère occidentale et judéo-chrétienne-examinent donc les différents éléments réutilisés dans les recompositions littéraires (II), le réseau d'analogies qu'on trouve dans les traditions mythologiques, religieuses et littéraires (III: Déchiffrages, recodages) et les réélaborations modernes (IV: Résurgences, Résonances: Arlequin, autres figures, chasses sauvages, jusqu'au Père Noël). Bibliographie (pp. 729-757) et index (auteurs, personnages, œuvres, notions et motifs, pp. 759-771) terminent le volume. 